\title{
Spiritual Emotional Freedom Technique (SEFT) terhadap Kualitas Hidup Penderita Tuberkulosis Paru
}

\author{
Kusnanto, Retnayu Pradanie, Inas Alifi Karima \\ Fakultas Keperawatan, Universitas Airlangga \\ Email:kusnanto_ners@yahoo.com/rena.unair@gmail.com
}

\begin{abstract}
Abstrak
Tuberkulosis paru (TB) merupakan penyakit kronik yang dapat memengaruhi kualitas hidup seseorang. Spiritual Emotional Freedom Technique (SEFT) merupakan salah satu terapi non-farmakologis untuk mengatasi hal tersebut. Penelitian ini bertujuan untuk menjelaskan pengaruh terapi SEFT terhadap peningkatan Quality of Life (QoL) pada penderita TB di Puskesmas Perak Timur Surabaya. Metode yang digunakan dalam penelitian ini adalah quasi-eksperimental dengan jumlah sampel yang memenuhi kriteria inklusi sebanyak 22 orang. Analisis data dilakukan dengan menggunakan uji Wilcoxon dan Mann Whitney dengan tingkat kemaknaan $\alpha<0,05$. Hasil penelitian menunjukkan adanya peningkatan kualitas hidup pasien TB secara signifikan pada aspek kesehatan fisik $(p=0,003)$, psikologis $(p=0,003)$, dan sosial $(p=0,046)$ setelah dilakukan intervensi SEFT. Sedangkan hasil tidak signifikan terdapat pada aspek lingkungan $(p=1,000)$. Pada uji Mann Whitney didapatkan hasil signifikan pada aspek kesehatan fisik $(p=0,000)$, aspek psikologis $(p=0,000)$, dan aspek fungsi sosial $(p=0,015)$. Hasil uji Mann Whitney tidak signifikan pada aspek lingkungan $(p=0,167)$. Kesimpulan yang didapatkan adalah SEFT mampu meningkatkan kualitas hidup responden secara umum, karena mampu mengatasi "psychological reversal" dan karena pengaruh dari "electrical active cells".
\end{abstract}

Kata kunci: SEFT, tuberkulosis paru, quality of life.

\section{Spiritual Emotional Freedom Technique (SEFT) and the Quality of Life of People Living with Lung Tuberculosis}

\begin{abstract}
The quality of life of people affected by Lung Tuberculosis may be challenged due to several factors. Spiritual Emotional Freedom Technique (SEFT) is considered as non-pharmacologic therapy to resolve emotioanl problems. This quasi-experitmental study aimed to examine the effect of SEFT towards Quality of Life (QoL) among TB people in Puskesmas Perak Timur Surabaya. 22 subjects were recruited following the inclusion criteria. Data were analysis using Wilcoxon and Mann Whitney with $\alpha<0,05$. Findings demontrated a significant increased of quality of life in terms of physical health $(p=0,003)$, psychological $(p=0,003)$ and social $(p=0,046)$ after SEFT intervention. However, environment aspect was not significant $(p=0,000)$. Using Mann Whitney, a significant increased found in terms of physical health $(p=0,000)$, psychological aspect $(p=0,000)$, and social function $(p=0,015)$. Environtment aspect was not significant $(p=0,167)$. It is suggested that SEFT can help to improve the quality of life of TB people due to pscyhological reversal and the effect of electrical active cells.
\end{abstract}

Keywords: Lung tuberculosis, quality of life, SEFT. 
Kusnanto : Spiritual Emotional Freedom Technique terhadap Kualitas Hidup Penderita TB Paru

\section{Pendahuluan}

Tuberkulosis paru merupakan salah satu penyakit paling mematikan di dunia. TB paru merupakan penyakit infeksi yang disebabkan oleh Mycobacterium tuberculosis dan bersifat menular (Suharyo, 2013). Penyakit Tuberculosis diperkenalkan oleh Robert Koch di Berlin, Jerman pada 24 Maret 1882 (Lestari et al., 2014). Penyakit tersebut menyebabkan masalah kesehatan pada jutaan orang di setiap tahun dan menempati urutan kedua penyakit infeksi yang menyebabkan kematian setelah Human Immunodeficiency Virus (HIV). Tuberkulosis paru merupakan ancaman bagi penduduk Indonesia. Kesembuhan TBC paru di Indonesia masih terdapat daerah tertentu yang angka kesembuhanya masih rendah (Muniroh et al., 2013). Penyakit tersebut merupakan penyakit kronik yang dapat memengaruhi kualitas hidup penderitanya. Pasien yang hidup dengan tuberkulosis (TB) mengalami gangguan yang signifikan dari kehidupan sosial mereka dan terkena stigma dan diskriminasi (Abioye, Omotayo, Alakija, 2011). Tuberkulosis paru menimbulkan permasalahan yang serius, pada konsep kualitas hidup yang terdiri dari aspek kesehatan fisik, psikologis, sosial, dan lingkungan (Nursalam, 2013). Ada konsensus bahwa kualitas hidup terkait kesehatan merupakan suatu konsep multidimensional yang disusun oleh 3 domain/determinan utama yaitu aspek fisik, emosi, dan sosial. Domain ini didasarkan pada pengertian sehat menurut WHO (Gurkova, 2011). Jumlah penderita Penyakit tuberkulosis paru terdapat di Puskesmas Perak Timur Surabaya yang mengalami peningkatan setiap tahunnya. Pada tahun 2012 terdapat 114 kasus di Puskesmas Perak Timur Surabaya, tahun 2013 terdapat 291 kasus, dan tahun 2015 terdapat 323 kasus. Berdasarkan hasil wawancara saat pengambilan data awal pada pasien tuberkulosis paru, mereka menjelaskan bahwa setelah terkena penyakit tuberkulosis paru ini kesehatan fisik menurun sehingga mengganggu aktivitas, meningkatkan kecemasan, memengaruhi hubungan sosial dengan lingkungan, dan lain sebagainya. Hal tersebut dapat memengaruhi kualitas hidup penderita TB paru tersebut.

Saat ini pelayanan yang tersedia bagi penyakit TB paru di Poliklinik Paru Puskesmas Perak Timur Surabaya terdiri dari pengobatan farmakologis (OAT), dan kunjungan rumah yang dilakukan oleh perawat puskesmas. Tetapi belum terdapat kebijakan yang mengharuskan pengobatan non-farmakologis untuk pengobatan TB walaupun telah banyak hasil penelitian yang menyebutkan manfaat dari terapi nonfarmakologis. Terapi Spiritual Emotional Freedom Technique (SEFT) merupakan terapi non-farmakologis yang berfokus pada nilai spiritualitas. Namun, terapi SEFT belum digunakan pada penyakit tuberkulosis paru. Sehingga pengaruh Spiritual Emotional Freedom Technique untuk meningkatkan kualitas hidup pada pasien tuberkulosis paru belum dapat dijelaskan.

Berdasarkan World Health Organization (WHO), prevalensi TB paru di Indonesia menempati urutan ketiga setelah India dan China yaitu hampir 700 kasus. Sementara itu angka kematian masih tetap 27 per 100.000 penduduk (Suharyo, 2013). Jumlah kematian (mortality) akibat TB paru di Indonesia adalah 64.000 orang (27/100.000 penduduk). Berarti dalam setiap hari terdapat 175 orang penderita TB paru di Indonesia yang meninggal. Dalam hal ini Provinsi Jawa Timur menduduki peringkat kedua setelah Provinsi Jawa Barat. Jumlah penderita TB paru di Jawa Timur tahun 2012 sebanyak 41.472 orang dan 1.233 diantaranya meninggal. Kota Surabaya menempati urutan kedua di Jawa Timur setelah kota Jember. Daerah dengan peringkat 3 tertinggi penderita TB paru dalam 3 bulan terakhir (Januari, Febuari, dan Maret 2013) di Surabaya adalah Perak Timur (94), Dupak (75), dan Pegirian (45) (Dinas Kesehatan Provinsi Jawa Timur, 2013). Terjadi peningkatan jumlah penderita TB paru di Puskesmas Perak Timur Surabaya dari tahun 2012 sampai 2014. Terdapat 114 kasus TB paru dengan rincian 47 kasus BTA (+) (28 laki-laki, 19 perempuan), kasus baru BTA (-) Ro+, dan ekstra paru sebanyak 67 kasus (42 laki-laki, 25 perempuan) (Dinas Kesehatan Provinsi Jawa Timur, 2012). Tingginya jumlah kasus TB yang ditemukan pada beberapa daerah di Indonesia termasuk pada Propinsi Jawa Timur, menggambarkan bahwa di Indonesia penyakit TB masih menjadi masalah kesehatan masyarakat 
Kusnanto : Spiritual Emotional Freedom Technique terhadap Kualitas Hidup Penderita TB Paru

yang penting dan utama yang harus segara ditanggulangi penyebarannya (Prasetyowati I \& Chatarina, 2009)

Penelitian pendahuluan yang dilakukan di Puskesmas Perak Timur Surabaya, didapatkan data pada tahun 2013 jumlah suspek TB paru sebanyak 291 kasus, kasus BTA (+) sebanyak 90 kasus (61 dewasa, 29 anak), BTA (-) Ro+ sebanyak 32 kasus, dan ekstra paru sebanyak 9 kasus (5 dewasa, 4 anak). Pada tahun 2014 kasus tuberkulosis paru di Puskesmas Perak Timur Surabaya mengalami peningkatan, jumlah suspek sebanyak 323 kasus, kasus BTA (+) sebanyak 98 kasus (76 dewasa, 12 anak), BTA (-) Ro+ sebanyak 57 kasus, dan Ekstra paru sebanyak 54 kasus (27 dewasa, 27 anak). Data tersebut menunjukkan bahwa terjadi peningkatan jumlah kasus di Puskesmas Perak Timur Surabaya dari tahun 2012 sampai 2014.

Penyakit TB paru yang diderita oleh individu dalam kehidupannya akan membawa akibat baik secara fisik, mental, maupun kehidupan sosialnya. Dampak buruk pada aspek kesehatan fisik, psikologis, hubungan sosial, dan lingkungan akan menurunkan kualitas hidup penderita tuberkulosis. Secara fisik jika seorang penderita TB paru yang tidak mendapat pengobatan, maka setelah 5 tahun penderita akan meninggal (50\%), akan sembuh sendiri dengan daya tahan tubuh yang tinggi (25\%), dan akan menjadi kasus kronis yang tetap menular $(25 \%)$. Faktor fisik yang kurang baik akan membuat seseorang kehilangan kesempatan untuk mengaktualisasikan dirinya disebabkan keterbatasan fisik yang dimiliki. Keterbatasan tersebut akan menghambat pencapaian kesejahteraan fisik, yang pada akhirnya akan berdampak pada kualitas hidup yang rendah. Menurut Depkes RI (2011), sekitar 75\% penderita TB paru adalah kelompok usia yang paling produktif secara ekonomis (1550 tahun). Diperkirakan seorang penderita TB paru dewasa, akan kehilangan rata-rata waktu kerjanya sampai 3 sampai 4 bulan. Hal tersebut berakibat pada kehilangan pendapatan tahunan rumah tangga sekitar 20$30 \%$. Jika ia meninggal akibat TB paru, maka akan kehilangan pendapatan sekitar 15 tahun. Selain merugikan secara ekonomis, TB paru juga memberikan dampak buruk lainnya secara sosial, diantaranya stigma bahkan dikucilkan oleh masyarakat. Menurunnya aktivitas sosial akan berdampak buruk pada kebermaknaan hidup dan menurunnya harga diri penderita tuberkulosis paru, hal tersebut akan berdampak negatif pada kualitas hidup. Ketidakstabilan psikologis menjadi salah satu faktor dalam menurunkan kesejahteraan psikologis yang akan berdampak negatif terhadap kualitas hidup penderita TB paru. Isolasi untuk mencegah penularan dari Mycobacterium tuberculosis dapat menimbulkan stigma sosial dari lingkungan sehingga memengaruhi psikologis pada pasien, yaitu timbulnya depresi, kecemasan, dan stress. Dampak dari beban psikologis pada pasien tuberkulosis paru akan memperburuk kesehatan fisik sehingga akan menurunkan kualitas hidup pasien. Ketidakberdayaan penderita TB akan menimbulkan perubahan adaptasi pada respon psikologis, sosial, dan spiritual sehingga akan berpengaruh terhadap Quality of Life (QoL) penderitanya.

Terapi SEFT dikembangkan dari Emotional Freedom Technique (EFT), oleh Gary Craig (USA), yang saat ini sangat populer di Amerika, Eropa, dan Australia sebagai solusi tercepat dan termudah untuk mengatasi berbagai masalah fisik, dan emosi, serta untuk meningkatkan performa kerja (Zainuddin, 2012). Penelitian sebelumnya menjelaskan SEFT sudah digunakan sebagai terapi pada penyakit hipertensi, gagal ginjal kronik, dan epilepsi. Pada penyakit epilepsi, SEFT digunakan sebagai terapi menajemen stres. Kekuatan spiritual dalam terapi SEFT bertujuan untuk menetralisir fenomena biokimiawi (acethilcolin), sehingga mencegah kambuhnya kejang dan memengaruhi frekuensi serangan kejang pada penderita epilepsi (Lasman, 2013). Menurut Fisher \& Brumley (2008) pengaruh spiritual terhadap kualitas hidup yaitu pasien yang memiliki kesehatan spiritual akan dapat berhubungan dengan kekuasaan tertinggi, dia memiliki arti dan tujuan hidup, dapat lebih baik pertahanannya dengan penyakit kronisnya. SEFT juga terbukti berpengaruh terhadap penurunan tekanan darah systole dan diastole (Virgianti, 2011). Dr. Paul Swingle dari Vancouver, Canada melaporkan bahwa penggunaan EFT dapat mengurangi frekuensi maupun intensitas kejang pada penderita epilepsi (Zainuddin, 2012). 
Kusnanto : Spiritual Emotional Freedom Technique terhadap Kualitas Hidup Penderita TB Paru

Terapi SEFT terdiri dari dua aspek, yaitu spiritual dan biologis. Menurut Wright (2002) spiritualitas adalah bagaimana kita mendefinisikan diri sebagai individu dan mencari makna serta tujuan dalam kehidupan kita. Aspek spiritual terdiri dari dua langkah, yaitu Set-Up yang bertujuan untuk memastikan agar aliran energi tubuh kita terarahkan dengan tepat. Langkah ini dilakukan untuk menetralisir "psychological reversal" atau "perlawanan psikologis", dan berisi doa kepasrahan. Langkah kedua adalah Tune-In dengan cara merasakan rasa sakit yang kita alami, lalu mengarahkan pikiran kita ke tempat rasa sakit (Self-Hypnosis). Aspek kedua adalah aspek biologi, yang terdiri dari tapping atau ketukan ringan pada 18 titik energi tubuh (The Major Energy Meridians) yang akan menimbulkan potensial aksi. Ketukan yang dilakukan akan merangsang "electrically active cells" sebagai pusat aktif yang terdiri dari kumpulan sel aktif yang ada di permukaan tubuh. Tapping dalam SEFT akan menimbulkan hantaran rangsang berupa sinyal transduksi yang terjadi dalam proses biologik akibat rangsangan pada titik utama SEFT. Jalur meridian spesifik yang berkaitan dengan tuberkulosis paru adalah meridian paru.

Terapi SEFT yang sudah dilakukan akan menimbulkan keikhlasan bagi pasien, sehingga pasien akan menerima dengan positif penyakit yang sedang dialami melalui ketabahan hati, harapan sembuh, serta mampu mengambil hikmah. Hal tersebut akan meningkatkan kualitas hidup pasien tuberkulosis paru, dengan indikator perbaikan pada aspek fisik, sosial, dan psikologis. SEFT dipilih untuk meningkatkan kualitas hidup karena SEFT berfokus pada peningkatan spiritual dari pasien TB paru. Spiritual dan kesehatan adalah dua hal yang berkaitan. Bukti-bukti ilmiah mengatakan bahwa pada penyakit yang umum sekalipun, kondisi pikiran, emosi, sikap, kesadaran, dan doadoa yang dipanjatkan oleh atau untuk pasien sangat berpengaruh bagi kesembuhannya. Hal tersebut akan berdampak positif pada peningkatan kualitas hidup pasien.

\section{Metode Penelitian}

Penelitian ini menggunakan desain quasieksperimental dengan rancangan Pretestpostest control group design yang melibatkan kelompok kontrol dan kelompok perlakuan. Populasi dalam penelitian ini yaitu penderita tuberkulosis paru di Puskesmas Perak Timur Surabaya selama bulan Januari sampai April 2015. Teknik sampling dalam penelitian ini menggunakan nonprobability sampling (purposive sampling) yaitu dengan memilih sampel diantara populasi sesuai dengan kriteria yang dikehendaki peneliti (Nursalam, 2013). Besar sampel penelitian ini menggunakan rumus besar sampel untuk uji hipotesis terhadap 2 proporsi (Sudigdo \& Sofyan, 2011), sehingga diperoleh masingmasing kelompok sejumlah 11 responden. Kriteria inklusi dalam penelitian ini adalah: 1) penderita $\mathrm{TB}$ paru yang menjalani pengobatan di Puskesmas Perak Timur Surabaya, 2) beragama Islam, 3) pasien TB paru fase intensif, 4) dapat berkomunikasi dengan baik, 5) berumur 25-60 tahun, 6) tingkat kesadaran komposmentis. Kriteria eksklusi penelitian ini adalah: 1) penderita TB paru dengan komplikasi seperti sindrom gagal napas dewasa dan keadaan lain seperti open injury yang terjadi di daerah tapping, 2) penderita TB paru yang tidak kooperatif.

Variabel independen pada penelitian ini adalah Spiritual Emotional Freedom Technique (SEFT). Sedangkan variabel dependen adalah kualitas hidup. Instrumen untuk kualitas hidup berupa kuisioner WHOQOL-BREF yang terdiri dari dua bagian yang berasal dari kualitas hidup secara menyeluruh dan kesehatan secara umum serta satu bagian yang terdiri dari 24 pertanyaan yang berasal dari WHOQOL-100. World Health Organization (WHO) telah mengembangkan sebuah instrumen untuk mengukur kualitas hidup seseorang yaitu WHO Quality of Life-BREF (WHOQOLBREF). WHOQOL-BREF terdiri dari empat domain yaitu fisik, psikologik, sosial dan lingkungan (Salim et al., 2007). Kuesinoer tersebut diberikan ketika pre-test dan post test. Proses penelitian ini berlangsung selama 1 bulan, dengan pembagian 2 minggu untuk 
Kusnanto : Spiritual Emotional Freedom Technique terhadap Kualitas Hidup Penderita TB Paru

kelompok kontrol dan 2 minggu untuk kelompok perlakuan. Data yang terkumpul kemudian dianalisis menggunakan uji statistik Wilcoxon signed rank test dengan tingkat kemaknaan $\alpha \leq 0,05$. Artinya, bila menghasilkan $(\mathrm{p}) \leq 0,05$, maka $\mathrm{H} 1$ diterima, hal ini berarti ada pengaruh terapi SEFT terhadap peningkatan Quality of Life (QoL) penderita TB paru. Untuk melihat perbedaan antara kelompok kontrol dan perlakuan dilakukan uji Mann Whitney $U$ test dengan tingkat kemaknaan $\alpha \leq 0,05$.

\section{Hasil Penelitian}

Data demografi responden menguraikan tentang karakteristik responden yang meliputi 1) jenis kelamin, 2) umur, 3) pekerjaan, 4) pendidikan, 5) lama pengobatan Tuberkulosis paru diperoleh hasil pada tabel 1 .

Setelah dilakukan analisa data dan menguji hasil penelitian secara kuantitatif (dengan uji statistik Wilcoxon signed rank test dan Mann Whitney U Test) diperoleh hasil pada tabel 2. Hasil uji statistik menggunakan Wilcoxon signed rank test, pada kelompok perlakuan (kelompok yang mendapatkan Terapi SEFT) adalah $p=0,003$ pada domain kesehatan fisik berarti $p \leq 0,05$ maka hipotesis diterima artinya ada pengaruh yang signifikan dari terapi SEFT terhadap peningkatan kualitas hidup (domain kesehatan fisik) pada penderita Tuberkulosis paru. Hasil uji statistik menggunakan Wilcoxon Signed Rank test, pada kelompok kontrol (kelompok yang tidak mendapatkan terapi SEFT) adalah $p=0,317$ pada domain kesehatan fisik yang berarti tidak ada perbedaan kualitas hidup (domain kesehatan fisik) pada penderita Tuberkulosis paru antara pretest dan posttest. Perbedaan rata-rata kualitas hidup (domain kesehatan fisik) saat pretest pada kelompok perlakuan dan kelompok kontrol dengan menggunakan uji Mann Whitney $U$ Test didapatkan $p=$ 0,167 , hal ini menunjukkan bahwa tidak ada perbedaan rata-rata antara kelompok kontrol dan kelompok perlakuan. Perbedaan ratarata kualitas hidup (domain kesehatan fisik) saat posttest pada kelompok perlakuan dan kelompok kontrol dengan menggunakan uji Mann Whitney U Test didapatkan $p=0,000$, hal ini menunjukkan bahwa ada perbedaan rerata peningkatan kualitas hidup (domain kesehatan fisik) antara kelompok perlakuan (kelompok yang mendapatkan terapi SEFT) dan kelompok kontrol (kelompok yang tidak mendapatkan terapi SEFT).

Pada domain psikologis, hasil uji statistik menggunakan Wilcoxon Signed Rank test, pada kelompok perlakuan adalah $p=0,003$ berarti $p \leq 0,05$ maka hipotesis diterima artinya ada pengaruh yang signifikan dari terapi SEFT terhadap peningkatan kualitas hidup (domain psikologis) pada penderita tuberkulosis paru. Sedangkan pada kelompok kontrol nilai $p=0,317$ berarti $p \geq$ 0,05 maka hipotesis ditolak artinya tidak ada terdapat peningkatan kualitas hidup (domain psikologis) pada penderita tuberkulosis paru. Perbedaan rata-rata kualitas hidup (domain psikologis) saat pretest pada kelompok perlakuan dan kelompok kontrol dengan menggunakan uji Mann Whitney $U$ test didapatkan $p=0,167$, hal ini menunjukkan bahwa tidak ada perbedaan rata-rata antara kelompok kontrol dan kelompok perlakuan. Perbedaan rata-rata kualitas hidup (domain

Tabel 1 Tabel Distribusi Responden berdasarkan Karakteristik Demografi pada Kelompok Perlakuan dan Kontrol Sebelum dan Sesudah diberikan Terapi SEFT pada Pasien Tuberkulosis Paru di Puskesmas Perak Timur Surabaya.

\begin{tabular}{lcccc}
\hline \multicolumn{1}{c}{$\begin{array}{c}\text { Demografi } \\
\text { Responden }\end{array}$} & F $(\Sigma)$ kontrol & \% kontrol & F $(\Sigma)$ perlakuan & \% perlakuan \\
\hline Jenis Kelamin & 5 & $45,5 \%$ & 5 & $45,5 \%$ \\
Laki-laki & 6 & $54,5 \%$ & 6 & $54,5 \%$ \\
Perempuan & 11 & $100 \%$ & 11 & $100 \%$ \\
$\Sigma$ Responden & & & & $18,2 \%$ \\
Umur & 0 & $0 \%$ & 2 & \\
$>25-\leq 35$ & & & & \\
\hline
\end{tabular}


Kusnanto : Spiritual Emotional Freedom Technique terhadap Kualitas Hidup Penderita TB Paru

\begin{tabular}{|c|c|c|c|c|}
\hline $\begin{array}{l}\text { Demografi } \\
\text { Responden }\end{array}$ & 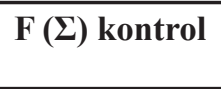 & \% kontrol & $F(\Sigma)$ perlakuan & \% perlakuan \\
\hline$>35-\leq 45$ & 3 & $27,3 \%$ & 3 & $27,3 \%$ \\
\hline$>45-\leq 60$ & 8 & $72,7 \%$ & 6 & $54,5 \%$ \\
\hline$\Sigma$ Responden & 11 & $100 \%$ & 11 & $100 \%$ \\
\hline \multicolumn{5}{|l|}{ Pekerjaan } \\
\hline Ibu Rumah Tangga & 3 & $27,27 \%$ & 3 & $27,27 \%$ \\
\hline Swasta/Karyawan & 0 & $0 \%$ & 4 & $36,36 \%$ \\
\hline $\begin{array}{l}\text { Pedagang/ } \\
\text { Wirausaha }\end{array}$ & 3 & $27,27 \%$ & 1 & $9,09 \%$ \\
\hline Sopir & 3 & $27,27 \%$ & 0 & $0 \%$ \\
\hline Tidak Bekerja & 2 & $18,19 \%$ & 3 & $27,28 \%$ \\
\hline$\Sigma$ Responden & 11 & $100 \%$ & 11 & $100 \%$ \\
\hline \multicolumn{5}{|l|}{ Pendidikan } \\
\hline Tidak sekolah & 2 & $18,19 \%$ & 0 & $0 \%$ \\
\hline Pendidikan Dasar & 6 & $54,54 \%$ & 9 & $81,76 \%$ \\
\hline SMA & 3 & $27,27 \%$ & 1 & $9,12 \%$ \\
\hline Perguruan Tinggi & 0 & $0 \%$ & 1 & $9,12 \%$ \\
\hline$\Sigma$ Responden & 11 & $100 \%$ & 11 & $100 \%$ \\
\hline \multicolumn{5}{|l|}{ Lama Pengobatan } \\
\hline $1-2$ bulan & 3 & $27,27 \%$ & 3 & $27,27 \%$ \\
\hline 2-3 bulan & 7 & $63,64 \%$ & 6 & $54,54 \%$ \\
\hline 3-4 bulan & 1 & $9,09 \%$ & 2 & $18,19 \%$ \\
\hline$\Sigma$ Responden & 11 & $100 \%$ & 11 & $100 \%$ \\
\hline
\end{tabular}

Tabel 2 Distribusi Quality of Life (Domain Kesehatan Fisik) pada Kelompok Perlakuan dan Kontrol Sebelum dan Sesudah Diberikan Terapi SEFT pada Pasien Tuberkulosis Paru di Puskesmas Perak Timur Surabaya

\begin{tabular}{|c|c|c|c|c|c|c|c|c|c|}
\hline \multirow[t]{3}{*}{ No } & \multirow[t]{3}{*}{ Kesehatan Fisik } & \multicolumn{4}{|c|}{ Kelompok Perlakuan } & \multicolumn{4}{|c|}{ Kelompok Kontrol } \\
\hline & & \multicolumn{2}{|c|}{ Pre } & \multicolumn{2}{|c|}{ Post } & \multicolumn{2}{|c|}{ Pre } & \multicolumn{2}{|c|}{ Post } \\
\hline & & $\mathbf{N}$ & $\%$ & $\mathbf{N}$ & $\%$ & $\mathbf{N}$ & $\%$ & $\mathbf{N}$ & $\%$ \\
\hline 1 & Kurang & 0 & 0 & 0 & 0 & 2 & 18,18 & 1 & 9,10 \\
\hline 2 & Cukup & 10 & 90,91 & 1 & 9,09 & 9 & 81,81 & 9 & 81,81 \\
\hline 3 & Baik & 1 & 9,09 & 10 & 90,91 & 0 & 0 & 1 & 9,09 \\
\hline 4 & Sangat Baik & 0 & 0 & 0 & 0 & 0 & 0 & 0 & 0 \\
\hline & Total & 11 & 100 & 11 & 100 & 11 & 100 & 11 & 100 \\
\hline
\end{tabular}

Mann Whitney U test

psikologis) saat posttest pada kelompok perlakuan dan kelompok kontrol dengan menggunakan uji Mann Whitney $U$ Test didapatkan $p=0,000$, hal ini menunjukkan bahwa ada perbedaan rerata peningkatan
Pretest $p=0,167$

Posttest $p=0,000$

kualitas hidup (domain psikologis) antara kelompok perlakuan (kelompok yang mendapatkan Terapi SEFT) dan kelompok kontrol (kelompok yang tidak mendapatkan terapi SEFT). 
Kusnanto : Spiritual Emotional Freedom Technique terhadap Kualitas Hidup Penderita TB Paru

Tabel 3 Distribusi Quality of Life (Domain Psikologis) pada Kelompok Perlakuan dan Kontrol Sebelum dan Sesudah Diberikan Terapi SEFT pada Pasien Tuberkulosis Paru di Puskesmas Perak Timur Surabaya

\begin{tabular}{|c|c|c|c|c|c|c|c|c|c|}
\hline \multirow[t]{3}{*}{ No } & \multirow[t]{3}{*}{ Psikologis } & \multicolumn{4}{|c|}{ Kelompok Perlakuan } & \multicolumn{4}{|c|}{ Kelompok Kontrol } \\
\hline & & \multicolumn{2}{|c|}{ Pre } & \multicolumn{2}{|c|}{ Post } & \multicolumn{2}{|c|}{ Pre } & \multicolumn{2}{|c|}{ Post } \\
\hline & & $\mathbf{n}$ & $\%$ & $\mathbf{n}$ & $\%$ & $\mathbf{n}$ & $\%$ & $\mathbf{n}$ & $\%$ \\
\hline 1 & Kurang Stabil & 0 & 0 & 0 & 0 & 1 & 9,09 & 0 & 0 \\
\hline 2 & Cukup Stabil & 10 & 90,91 & 1 & 9,09 & 10 & 90,91 & 11 & 100 \\
\hline 3 & Stabil & 1 & 9,09 & 10 & 90,91 & 0 & 0 & 0 & 0 \\
\hline 4 & Sangat Stabil & 0 & 0 & 0 & 0 & 0 & 0 & 0 & 0 \\
\hline & Total & 11 & 100 & 11 & 100 & 11 & 100 & 11 & 100 \\
\hline \multicolumn{2}{|c|}{ Wilcoxon signed rank test } & \multicolumn{4}{|c|}{$p=0,003$} & \multicolumn{4}{|c|}{$p=0,317$} \\
\hline \multicolumn{2}{|c|}{ Mann Whitney U test } & \multicolumn{8}{|c|}{$\begin{array}{l}\text { Pretest } p=0,167 \\
\text { Posttest } p=0,000\end{array}$} \\
\hline
\end{tabular}

Tabel 4 Distribusi Quality of Life (Domain Sosial) pada Kelompok Perlakuan dan Kontrol Sebelum dan Sesudah Diberikan Terapi SEFT pada Pasien Tuberkulosis Paru di Puskesmas Perak Timur Surabaya

\begin{tabular}{|c|c|c|c|c|c|c|c|c|c|}
\hline \multirow[t]{3}{*}{ No } & \multirow[t]{3}{*}{ Sosial } & \multicolumn{4}{|c|}{ Kelompok Perlakuan } & \multicolumn{4}{|c|}{ Kelompok Kontrol } \\
\hline & & \multicolumn{2}{|c|}{ Pre } & \multicolumn{2}{|c|}{ Post } & \multicolumn{2}{|c|}{ Pre } & \multicolumn{2}{|c|}{ Post } \\
\hline & & $\mathbf{n}$ & $\%$ & $\mathbf{n}$ & $\%$ & $\mathbf{n}$ & $\%$ & $\mathbf{n}$ & $\%$ \\
\hline 1 & Kurang Aktif & 0 & 0 & 0 & 0 & 4 & 36,36 & 2 & 18,18 \\
\hline 2 & Cukup Aktif & 9 & 81,81 & 5 & 45,46 & 6 & 54,54 & 8 & 72,72 \\
\hline 3 & Aktif & 2 & 18,19 & 6 & 54,54 & 1 & 9,1 & 1 & 9,1 \\
\hline \multirow[t]{2}{*}{4} & Sangat Aktif & 0 & 0 & 0 & 0 & 0 & 0 & 0 & 0 \\
\hline & Total & 11 & 100 & 11 & 100 & 11 & 100 & 11 & 100 \\
\hline \multicolumn{2}{|c|}{ Wilcoxon signed rank test } & \multicolumn{4}{|c|}{$p=0,046$} & \multicolumn{4}{|c|}{$p=0,157$} \\
\hline \multicolumn{2}{|c|}{ Mann Whitney U test } & \multicolumn{8}{|c|}{$\begin{array}{l}\text { Pretest } p=0,061 \\
\text { Posttest } p=0,015\end{array}$} \\
\hline
\end{tabular}

Tabel 5 Distribusi Quality of Life (Domain lingkungan) pada Kelompok Perlakuan dan Kontrol Sebelum dan Sesudah Diberikan Terapi SEFT pada Pasien Tuberkulosis Paru di Puskesmas Perak Timur Surabaya

\begin{tabular}{|c|c|c|c|c|c|c|c|c|c|}
\hline \multirow[t]{3}{*}{ No } & \multirow[t]{3}{*}{ Lingkungan } & \multicolumn{4}{|c|}{ Kelompok Perlakuan } & \multicolumn{4}{|c|}{ Kelompok Kontrol } \\
\hline & & \multicolumn{2}{|c|}{ Pre } & \multicolumn{2}{|c|}{ Post } & \multicolumn{2}{|c|}{ Pre } & \multicolumn{2}{|c|}{ Post } \\
\hline & & $\mathbf{n}$ & $\%$ & $\mathbf{n}$ & $\%$ & $\mathbf{n}$ & $\%$ & $\mathbf{n}$ & $\%$ \\
\hline 1 & Kurang Memadai & 1 & 9,10 & 1 & 9,10 & 4 & 36,36 & 3 & 27,27 \\
\hline 2 & Cukup Memadai & 7 & 63,63 & 7 & 63,63 & 6 & 54,54 & 7 & 63,63 \\
\hline 3 & Memadai & 3 & 27,27 & 3 & 27,27 & 1 & 9,1 & 1 & 9,10 \\
\hline 4 & Sangat Memadai & 0 & 0 & 0 & 0 & 0 & 0 & 0 & 0 \\
\hline & Total & 11 & 100 & 11 & 100 & 11 & 100 & 11 & 100 \\
\hline \multicolumn{2}{|c|}{ Wilcoxon signed rank test } & \multicolumn{4}{|c|}{$p=1,000$} & \multicolumn{4}{|c|}{$p=0,564$} \\
\hline \multicolumn{2}{|c|}{ Mann Whitney U test } & \multicolumn{8}{|c|}{$\begin{array}{l}\text { Pretest } p=0,101 \\
\text { Posttest } p=0,167\end{array}$} \\
\hline
\end{tabular}


Kusnanto : Spiritual Emotional Freedom Technique terhadap Kualitas Hidup Penderita TB Paru

Pada domain sosial, hasil uji statistik menggunakan Wilcoxon signed ranktest, pada kelompok perlakuan adalah $p=0,046$ berarti $p \leq 0,05$ maka hipotesis diterima artinya ada pengaruh yang signifikan dari terapi SEFT terhadap peningkatan kualitas hidup (domain sosial) pada penderita tuberkulosis paru. Pada domain sosial, hasil uji statistik menggunakan Wilcoxon signed rank test, pada kelompok kontrol adalah $p=0,157$ berarti tidak ada perbedaan kualitas hidup (domain sosial) pada penderita tuberkulosis paru. Perbedaan rata-rata kualitas hidup (domain sosial) saat pretest pada kelompok perlakuan dan kelompok kontrol dengan menggunakan uji Mann Whitney $U$ test didapatkan $p=$ 0,061 , hal ini menunjukkan bahwa tidak ada perbedaan rata-rata antara kelompok kontrol dan kelompok perlakuan. Perbedaan rata-rata kualitas hidup (domain sosial) saat posttest pada kelompok perlakuan dan kelompok kontrol dengan menggunakan uji Mann Whitney $U$ test didapatkan $p=0,015$, hal ini menunjukkan bahwa ada perbedaan rerata peningkatan kualitas hidup (domain sosial) antara kelompok perlakuan (kelompok yang mendapatkan terapi SEFT) dan kelompok kontrol (kelompok yang tidak mendapatkan terapi SEFT).

Pada domain lingkungan, hasil uji statistik menggunakan Wilcoxon signed ranktest, pada kelompok perlakuan adalah $p=1,000$ berarti $p \geq 0,05$ maka hipotesis ditolak artinya tidak ada pengaruh yang signifikan dari terapi SEFT terhadap peningkatan kualitas hidup (domain lingkungan) pada penderita tuberkulosis paru. Hasil uji statistik menggunakan Wilcoxon signed rank test, pada kelompok kontrol adalah $p=0,564$ artinya tidak ada perbedaan yang signifikan pada kualitas hidup (domain lingkungan) antara pretest dan posttest pada penderita tuberkulosis paru. Perbedaan ratarata kualitas hidup (domain lingkungan) saat pre test pada kelompok perlakuan dan kelompok kontrol dengan menggunakan uji Mann Whitney $U$ test didapatkan $p=$ 0,101 , hal ini menunjukkan bahwa tidak ada perbedaan rata-rata antara kelompok kontrol dan kelompok perlakuan. Perbedaan ratarata kualitas hidup (domain kesehatan fisik) saat posttest pada kelompok perlakuan dan kelompok kontrol dengan menggunakan uji Mann Whitney UTest didapatkan $p=0,167$, hal ini menunjukkan bahwa tidak ada perbedaan rerata peningkatan kualitas hidup (domain lingkungan) antara kelompok perlakuan (kelompok yang mendapatkan terapi SEFT) dan kelompok kontrol (kelompok yang tidak mendapatkan terapi SEFT).

\section{Pembahasan}

Hasil penelitian pada tabel di atas menunjukkan perbedaan peningkatan Quality of Life terhadap domain kesehatan fisik, psikologis, dan sosial pada kelompok perlakuan pretest dan posttest melalui uji Wilcoxon dan uji Mann Whitney didapatkan bahwa H1 diterima yaitu ada pengaruh Spiritual Emotional Freedom Technique (SEFT) terhadap peningkatan Quality of Life dari domain kesehatan fisik, psikologis, dan sosial pada penderita tuberkulosis paru di Puskesmas Perak Timur Surabaya. Sedangkan pada domain lingkungan tidak ada perbedaan peningkatan Quality of Life yang signifikan pada kelompok perlakuan pre test dan posttest melalui uji Wilcoxon dan uji Mann Whitney didapatkan bahwa H1 ditolak, yaitu tidak ada pengaruh Spiritual Emotional Freedom Technique (SEFT) terhadap peningkatan Quality of Life. Hal tersebut menunjukkan intervensi yang diberikan peneliti berpengaruh terhadap peningkatan Quality of Life penderita tuberkulosis paru.

Tuberkulosis paru merupakan salah satu penyakit paling mematikan di dunia. TB paru merupakan penyakit infeksi yang disebabkan oleh Mycobacterium tuberculosis dan bersifat menular (Suharyo, 2013). Penyakit tersebut menyebabkan masalah kesehatan pada jutaan orang di setiap tahun dan menempati urutan kedua penyakit infeksi yang menyebabkan kematian setelah Human Immunodeficiency Virus (HIV). Tuberkulosis paru merupakan ancaman bagi penduduk Indonesia. Penyakit tersebut merupakan penyakit kronik yang dapat memengaruhi kualitas hidup penderitanya. Tuberkulosis paru menimbulkan permasalahan yang serius pada konsep kualitas hidup yang terdiri dari aspek kesehatan fisik, psikologis, sosial, dan lingkungan (Nursalam, 2013).

Dampak dari beban psikologis pada pasien Tuberkulosis paru akan memperburuk 
Kusnanto : Spiritual Emotional Freedom Technique terhadap Kualitas Hidup Penderita TB Paru

kesehatan fisik sehingga akan menurunkan kualitas hidup pasien. Ketidakberdayaan pasien Tuberkulosis paru akan menimbulkan perubahan adaptasi pada respon psikologis, sosial, dan spiritual sehingga akan berpengaruh terhadap Quality of Life (QoL) penderitanya. Hal tersebut sesuai dengan data pengukuran kualitas hidup yang dilakukan oleh peneliti. Dalam penelitian ini, dari 11 responden pada kelompok perlakuan, 9 orang memiliki status kesehatan fisik cukup dan 1 orang memiliki status kesehatan baik. Pada kelompok kontrol, 2 orang memiliki status kesehatan kurang dan 9 orang memiliki status kesehatan fisik cukup. Item pada kesehatan fisik yang dimaksud meliputi rasa sakit (batuk dan sesak pada TB paru, ketergantungan pada bahan obat dan bantuan medis, energi dan kelelahan, mobilitas, kepuasan tidur, kemampuan beraktivitas, dan kemampuan bekerja). Pada domain psikologis, dari 11 responden pada kelompok perlakuan, 10 orang memiliki status psikologis cukup stabil dan 1 orang memiliki status psikologis stabil. Menurut Burkhardt, L., \& Hogan, N. (2008), spiritualitas merupakan penemuan makna dan tujuan hidup yang memiliki hubungan erat dengan diri, orang lain, alam, sastra, seni, dan/atau kekuatan yang lebih besar dari dirinya sendiri. Pada kelompok kontrol, 1 orang memiliki status psikologis kurang stabil dan 10 orang memiliki status psikologis cukup stabil. Item pada psikologis yang dimaksud meliputi perasaan positif, penghargaan hidup, konsentrasi, tampilan tubuh, penghargaan diri, dan perasaan negatif. Pada domain sosial, dari 11 responden pada kelompok perlakuan, 9 orang memiliki status sosial cukup aktif dan 2 orang memiliki status sosial aktif. Pada kelompok kontrol, 4 orang memiliki status sosial kurang aktif, 6 orang memiliki status sosial cukup aktif, dan 1 orang memiliki status sosial aktif. Pada domain lingkungan, dari 11 responden pada kelompok perlakuan, 1 orang memiliki status lingkungan kurang memadai, 7 orang dengan domain lingkungan cukup memadai, dan 3 orang dengan domain lingkungan memadai.

Zainuddin (2012) mengatakan bahwa SEFT merupakan penggabungan antara spiritualitas melalui doa, keikhlasan, dan kepasrahan dengan energi psikologi. Teknik ini telah dibuktikan oleh berbagai macam riset ilmiah (Zainuddin, 2012). Teori utama yang menjadi acuan dasar dalam SEFT adalah energi psikolog. Spiritual Emotional Freedom Technique (SEFT) bekerja dengan prinsip yang kurang lebih sama dengan akupuntur dan akupressur. Akupuntur dan akupresur adalah teknik terapi yang menggunakan sistem energi tubuh untuk menyembuhkan berbagai penyakit fisik. Ketiga teknik ini berusaha merangsang titiktitik kunci di sepanjang 12 jalur energi (energi meridian) tubuh yang sangat berpengaruh pada kesehatan kita. Spiritual merupakan komponen yang membedakan antara SEFT dan EFT. Terdapat penambahan unsur spiritual dalam SEFT berupa doa kepada Tuhan. Penambahan unsur spiritual berupa doa tersebut menghasilkan amplifying effect atau efek pelipatgandaan pada EFT.

Pada pelaksanaan Terapi SEFT, terdapat tiga aspek yang perlu diperhatikan, yaitu Set $-U p$, Tune-In, dan Tapping. Set-Up berisikan doa penetralisir yang bermanfaat untuk "psychological reversal" atau "perlawanan psikologis", hal tersebut berpengaruh terhadap kesehatan psikologis (menimbulkan harapan, ketabahan, dan hikmah) dan pada aspek sosial, yaitu menetralkan emosi dan meminimalkan kecemasan. Tahap selanjutnya adalah Tune-In, dengan cara merasakan rasa sakit yang kita alami, lalu mengarahkan pikiran kita ke tempat rasa sakit, dibarengi dengan hati dan mulut kita berdoa. Bersamaan dengan Tune-In ini kita melakukan langkah ketiga (tapping). Pada proses inilah kita menetralisir emosi negatif atau rasa sakit fisik (Zainuddin, 2012). Pada tahap tapping ketukan yang dilakukan akan merangsang "electrically active cells" sebagai pusat aktif yang terdiri dari kumpulan sel aktif yang ada di permukaan tubuh. Tapping dalam SEFT akan menimbulkan hantaran rangsang berupa sinyal transduksi yang terjadi dalam proses biologik akibat rangsangan pada titik utama SEFT. Dua belas jalur utama meridian tubuh yang terdapat dalam SEFT adalah small intestine, triple heater, large intestine, stomach, liver, spleen, kidney, heart, governing vessel, lungs, bladder, dan gall bladder. Jalur meridian spesifik yang berkaitan dengan tuberkulosis paru adalah meridian paru. Reaksi rangsangan melalui titik-titik utama tapping pada SEFT akan 
Kusnanto : Spiritual Emotional Freedom Technique terhadap Kualitas Hidup Penderita TB Paru

mensekresikan ACTH yang merangsang produksi $\beta$ endorfin dan pro opiomularocortin yang mempunyai efek mengurangi reaksi inflamasi.

Kelompok perlakuan dari tabel 2 menunjukkan peningkatan kualitas hidup (domain kesehatan fisik) pada hampir semua responden. Sedangkan pada kelompok kontrol tidak mengalami perbedaan yang signifikan, karena berdasarkan penelitian yang dilakukan oleh Francis Galtoh pada tahun 1872, yang telah didokumentasikan oleh The Office of Prayer Research, telah dibuktikan bahwa doa dan spiritualitas memang berpengaruh kepada kesehatan (Zainuddin, 2012). Hal tersebut mendukung bahwa kelompok kontrol yang hanya diberikan pengobatan standar berupa OAT saja tanpa disertai dengan terapi SEFT tidak ditemukan perbedaan yang signifikan dalam aspek kesehatan fisik.

Kelompok perlakuan dari tabel 3 menunjukkan peningkatan kualitas hidup (domain psikologis) pada hampir semua responden. Terapi SEFT adalah terapi yang efektif dalam meningkatkan kesejahteraan psikologis responden dimana terapi ini menggunakan unsur spiritual berupa berdoa kepada Tuhan yang akan menghasilkan amplifying effect atau efek pelipatgandaan pada hasil SEFT itu sendiri. Doa merupakan dampak yang positif terhadap kondisi psikologis. Kondisi dan penerimaan yang baik akan meningkatkan kualitas hidup. Doa merupakan sarana yang dapat memperbaiki respon psikologis, sosial, dan spiritual sehingga akan berpengaruh terhadap Quality of Life (QoL) responden. Sedangkan pada kelompok kontrol tidak mengalami perbedaan yang signifikan, karena aspek psikologis pasien tuberkulosis paru yang tidak diberikan terapi SEFT dan hanya diberikan terapi standar oleh puskesmas menunjukkan perubahan yang tidak signifikan bahwa responden kelompok kontrol tidak mendapatkan terapi berdoa yang terstruktur dan berkelanjutan. Sehingga hal tersebut akan menimbulkan hambatan spiritual, yaitu kurang yakin (faith), kurang ikhlas (acceptance), kurang khusyu' (focus), kurang pasrah (surrender), dan kurang syukur (grateful). Hal tersebut akan menimbulkan perlawanan psikologis yang akan berpengaruh pada kesejahteraan psikologis yang rendah.
Kelompok perlakuan dari tabel 4 menunjukkan peningkatan kualitas hidup (domain sosial) pada hampir semua responden. Kesejahteraan sosial merupakan tata kehidupan dan penghidupan sosial, baik material maupun spiritual, yang diliputi rasa keselamatan, kesusilaan, dan ketentraman lahir batin untuk mengadakan pemenuhan kebutuhan jasmani, rohani, dan sosial yang sebaikbaiknya bagi diri, keluarga, serta masyarakat dengan menjunjung tinggi hak dan kewajiban asasi manusia (Anis, 2010). Hal tersebut mendukung bahwa spiritual merupakan salah satu aspek penting dalam terwujudnya kesejahteraan sosial. Aspek spiritual dapat dibangun dengan menumbuhkan 5 aspek dalam diri, yaitu keyakinan, keikhlasan, kekhusyukan, kepasrahan, dan rasa syukur. Kelima aspek tersebut merupakan syarat yang harus dibangun ketika melakukan terapi SEFT. Terapi SEFT merupakan salah satu sarana dalam mendukung spiritualitas pada individu. Kelompok perlakuan dari tabel 5 menunjukkan tidak menunjukkan peningkatan yang signifikan pada kualitas hidup (domain lingkungan). Domain lingkungan terdiri dari sumber daya keuangan, kebebasan, keamanan, kenyamanan fisik, kesehatan, dan kepedulian sosial (aksestabilitas dan kualitas), lingkungan rumah, peluang untuk memperoleh informasi dan keterampilan baru, partisipasi dan kesempatan untuk rekreasi, serta lingkungan fisik (polusi dan kebisingan) (Nursalam, 2013). Kesulitan finansial merupakan komponen yang tidak dipengaruhi terapi SEFT. Hal ini didasari oleh pemahaman bahwa SEFT merupakan terapi yang menggabungkan unsur doa dan spiritualitas (Zainuddin, 2012). Target dari SEFT adalah meingkatkan intensitas emosi, dan menimbulkan dampak perubahan drastis baik emosi maupun fisik (Octavia, 2009). SEFT tidak termasuk tindakan untuk mengatasi finansial seseorang.

Terapi SEFT yang sudah dilakukan akan menimbulkan keikhlasan bagi pasien, sehingga pasien akan menerima dengan positif penyakit tuberkulosis paru melalui ketabahan hati, harapan sembuh, serta mampu mengambil hikmah. Hal tersebut akan meningkatkan kualitas hidup dari pasien tuberkulosis, dengan indikator perbaikan pada aspek fisik, sosial, dan psikologis. 
Kusnanto : Spiritual Emotional Freedom Technique terhadap Kualitas Hidup Penderita TB Paru

\section{Simpulan}

Penerapan SEFT meningkatkan kualitas hidup penderita TB Paru pada domain kesehatan fisik, psikologis, dan sosial. Namun, penerapan SEFT tidak berpengaruh terhadap domain lingkungan pada kualitas hidup pasien tuberkulosis paru. Secara umum SEFT mampu meningkatkan kualitas hidup responden karena mampu mengatasi "psychological reversal" dan karena pengaruh dari "electrical active cells". Berdasarkan hasil penelitian ini, maka SEFT dapat direkomendasikan sebagai terapi tambahan bagi penderita TB agar dapat meningkatkan kualitas hidup penderita TB.

\section{Daftar Pustaka}

Abioye IA, Omotayo MO, Alakija. (2011). Socio-Demographic Determinants of Stigma among Patients with Pulmonary Tuberculosis in Lagos, Nigeria. Afr Health Sci (2011). 11 (Suppl 1): S100-4. doi: 10.4314/ahs. V11i3. 70078.

Anis. (2010). Analisis faktor dominan yang memengaruhi kualitas hidup lanjut usia berdasarkan WHOQoL (The World Health Organization Quality of Life) di Panti Werdha Hargo Dedali Surabaya (Skripsi). Program Studi S1 Keperawatan, Universitas Airlangga, Surabaya.

Burkhardt, L., \& Hogan, N. (2008). An experiential theory of spiritual care in nursing practice. Qualitative Health Research, 18 (7), 928-938

Depkes. (2011). Pedoman nasional penanggulangan tuberkulosis. Jakarta: Departemen Kesehatan Republik Indonesia.

Dinas Kesehatan Provinsi Jawa Timur. (2013). Profil kesehatan provinsi Jawa Timur tahun 2012. Surabaya: Dinas Kesehatan Provinsi Jawa Timur.

Fisher, J \& Brumley, D. (2008). Theory of Integral Nursing. Advances in Nursing Science Vol.31, No.1, pp. E52-E7.

Gurkova, E. (2011). Issue in The Definition of
HRQoL. Journal of Nursing, Social Studies, Public Health and Rehabilitation (3-4), 190 197.

Lasman. (2013). Pengaruh manajemen stres tehnik SEFT terhadap penurunan kejadian kejang pasien epilepsi di Poli Syaraf RSUD Dr. Iskak Tulungagung (Tesis). Program Studi Magister Keperawatan, Fakultas Keperawatan, Universitas Airlangga, Surabaya.

Lestari, RD, dkk. (2014). Pemodelan FaktorFaktor yang Mempengaruhi Jumlah Kasus Penyakit Tuberkulosis di Jawa Timur dengan Pendekatan Generalized Poisson Regression dan Geographically Weighted Poisson Regression. Jurnal Saind dan Seni PomITS. Vol. 3, No. 2, ISSN: 2337-3539.

Muniroh, N, Aisah, S \& Mifbakhuddin. (2013). Faktor-Faktor yang Berhubungan dengan Penyembuhan Penyakit Tuberkulosis (TBC) Paru di Wilayah Kerja Puskesmas Mangkang Semarang Barat. Jurnal Keperawatan Komunitas. Vol.1, No.1, 33-42

Nursalam. (2013). Metodologi penelitian ilmu keperawatan. Jakarta: Salemba Medika.

Octavia, N. (2009). Pengaruh emotional freedom technique (EFT) terhadap peningkatan harga diri narapidana perempuan (Tesis). Program Studi Magister Keperawatan, Fakultas Ilmu Keperawatan, Universitas Indonesia, Jakarta.

Sudigdo, I., \& Sofyan. (2011). Dasar-dasar metodologi penelitian klinis (Edisi ke-4). Jakarta: Sagung Seto.

Suharyo. (2013). Determinasi penyakit tuberkulosis di daerah pedesaan. Jurnal Kesehatan Masyarakat Universitas Dian Nuswantoro, Kemas, 9(1). Tersedia pada http:// journal.unnes.ac.id/nju/index.Php/kemas.

Virgianti. (2011). Pengaruh keperawatan spiritual emotional freedom technique (SEFT) islami terhadap tekanan darah penderita hipertensi usia 45-59 tahun di RSUD Dr. Soegiri Lamongan (Tesis). Program Studi Magister Keperawatan, Fakultas Keperawatan, Universitas Airlangga, Surabaya. 
Kusnanto : Spiritual Emotional Freedom Technique terhadap Kualitas Hidup Penderita TB Paru

Wright, S.G. (2002). Examining the impact freedom technique (SEFT). Jakarta: Afzan of spirituality on nurses and health-care Publishing.

Provision. Professional Nurse. 17 (12), 709-

711

Zainuddin, A.F. (2012). SEFT for healing and Zainuddin, A.F. (2012). Spiritual emotional $\begin{aligned} & \text { success, happiness } \\ & \text { Afzan Publishing. }\end{aligned}$ success, happiness and greatness. Jakarta: 